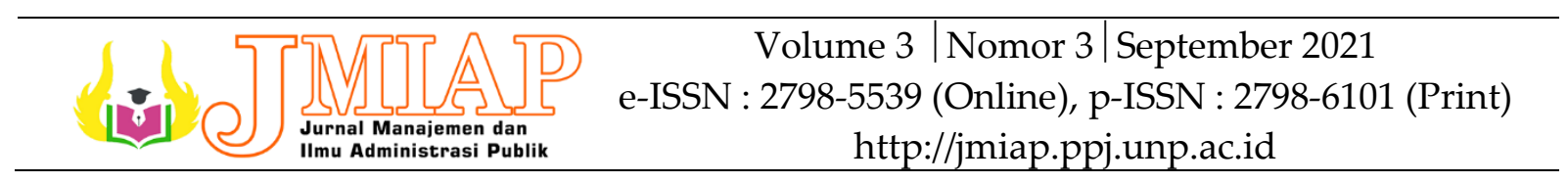

\title{
KOORDINASI PENGAWASAN BADAN PERMUSYAWARATAN NAGARI DENGAN WALI NAGARI DALAM PENYELENGGARAAN PEMERINTAHAN NAGARI MUARA SAKAI
}

\author{
Nur Afifah Agusma Yeni ${ }^{1(a)}$, Hasbullah Malau ${ }^{2(b)}$ \\ 1,2 Jurusan Ilmu Administrasi Negara, Universitas Negeri Padang

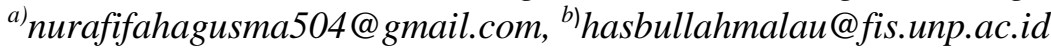

\begin{tabular}{l}
\multicolumn{1}{c}{\begin{tabular}{c}
\multicolumn{1}{c}{ INFORMASI } \\
ARTIKEL
\end{tabular}} \\
\hline Article History: \\
Dikirim: \\
16-07-2021 \\
Selesai Revisi: \\
03-09-2021 \\
Diterbitkan Online: \\
30-09-2021 \\
\end{tabular}

Kata Kunci:

Pengawasan, Wali Nagari, Badan Permusyawaratan Nagari

\begin{abstract}
Pemerintahan Nagari adalah penyelenggaraan urusan pemerintahan yang dilaksanakan oleh Pemerintah Nagari dan Badan Permusyawaratan Nagari (BAMUS). Wali Nagari sebagai penyelenggara pemerintahan sedangkan BAMUS sebagai lembaga pengawasan. Dalam melaksanakan fungsi pengawasan, BAMUS dan Wali Nagari perlu melakukan koordinasi agar pengawasan BAMUS berjalan dengan baik. Fenomena permasalahan yang terjadi yaitu terdapat beberapa hal terkait penyelenggaraan pemerintahan Nagari yang tidak diketahui oleh BAMUS. Akibatnya pengawasan BAMUS tidak menyeluruh. Metode penelitian yang digunakan dalam penelitian ini yaitu deskriptif kualitatif, mendeskripsikan fenomena sesuai dengan apa yang terjadi dilapangan. Penelitian ini dilakukan di Nagari Muara Sakai Kecamatan Pancung Soal Kabupaten Pesisir Selatan Provinsi Sumatera Barat. Hasil penelitian adalah koordinasi bidang pengawasan antara BAMUS dengan Wali Nagari Muara Sakai dilakukan melalui musyawarah nagari, rapat koordinasi, komunikasi secara lisan, BAMUS turun langsung kelapangan, dan laporan pertanggungjawaban. Koordinasi bidang pengawasan BAMUS dengan Wali Nagari Muara Sakai belum berjalan dengan cukup baik. Hal ini dikarenakan terdapat beberapa faktor yang menghambat koordinasi pengawasan BAMUS dengan Wali Nagari Muara Sakai yaitu komunikasi yang kurang baik antara BAMUS dengan Wali Nagari, ketidak sinkron-an tindakan antara BAMUS dan Wali Nagari di beberapa kegiatan, kurangnya gagasan BAMUS Nagari dalam melaksanakan fungsi pengawasan, dan kurangnya transparansi Wali Nagari mengenai beberapa kegiatan Nagari.
\end{abstract}

Keywords:

Supervision, Wali Nagari,

Nagari Consultative Body

Corresponding Author:

nurafifahagusma504@gmail.com

DOI:

https://doi.org/10.24036/jmiap.v3i3.274

\section{ABSTRACT}

Nagari Government is the administration of government affairs carried out by the Nagari Government and the Nagari Consultative Body (BAMUS). Wali Nagari is the administrator of the government, while BAMUS is the supervisory agency. In carrying out the supervisory function, BAMUS and Wali Nagari need to coordinate so that BAMUS supervision runs well. The phenomenon of the problems that occur is that there are several things related to the administration of Nagari government that are not known by BAMUS. As a result, BAMUS' supervision of Wali Nagari is not comprehensive. The research method used in this research is descriptive qualitative, describing phenomena according to what is happening in the field. This research was conducted in Nagari Muara Sakai, Pancung Problem District, Pesisir Selatan Regency, West Sumatra Province. The result of the research is that the coordination of supervision between BAMUS and Wali Nagari Muara Sakai is carried out through village deliberations, coordination meetings, verbal communication, BAMUS goes directly to the field, and accountability reports. The coordination in the supervision of BAMUS with the Wali Nagari Muara Sakai has not gone well enough. This is because there are several factors that hinder the coordination of BAMUS supervision with Wali Nagari Muara Sakai, namely poor communication between BAMUS and Wali Nagari, unsynchronized actions between BAMUS and Wali Nagari in several activities, lack of ideas for BAMUS Nagari in carrying out supervisory functions, and the lack of transparency of the Wali Nagari regarding some Nagari activities. 


\section{PENDAHULUAN}

Undang-undang Nomor 6 Tahun 2014 Tentang Desa, merupakan dasar pengakuan kembalinya nilai-nilai lokal ditingkat desa. Kearifan lokal ditingkat desa, yaitu Nagari mendapat pengakuan kembali setelah hampir 32 tahun mengalami penyeragaman berdasarkan UU Nomor 5 Tahun 1974 Tentang Pemerintahan Daerah (Malau, 2018).

Nagari merupakan satuan daerah terkecil yang berada di wilayah Provinsi Sumatera Barat, yang setingkat dengan desa, mengatur dan mengurus kepentingan masyarakat setempat berdasarkan filosofi dan sandi adat, Adat Basandi Syara' - Syara' Basandi Kitabullah. Sedangkan Pemerintahan Nagari menurut Peraturan Daerah Kabupaten Pesisir Selatan Nomor 8 Tahun 2007 tentang Pemerintahan Nagari, dalam pasal 1 Ayat (6) menyebutkan bahwa Pemerintahan Nagari adalah penyelenggaraan urusan pemerintahan yang dilaksanakan oleh Pemerintah Nagari dan Badan Permusyawaratan Nagari (BAMUS Nagari). Tujuan dari penyelenggaraan Pemerintahan Nagari adalah untuk menampung, menyalurkan, dan mewujudkan aspirasi masyarakat dalam mengembangkan kehidupannya yang sesuai dengan falsafah adat minangkabau.

Berdasarkan Peraturan Daerah Provinsi Sumatera BaratNomor 9 Tahun 2000 Tentang Ketentuan Pokok Pemerintahan Nagari,lembaga-lembaga yang dimiliki oeh Nagari (Wali Nagari, Kerapatan Adat Nagari, dan Badan Permusyawaratan Nagari) digunakan dalam penyelenggaraan Pemerintahan Nagari sesuai dengan nilai adat, dan aturan hanya berlaku pada Nagari tersebut (adat salingka Nagari) (Malau \& Akmal, 2020).

Menurut Peraturan Bupati Pesisir Selatan Nomor 26 Tahun 2017 tentang BAMUS Nagari, Badan Permusyawaratan Nagari yang selanjutnya disingkat BAMUS NAGARI adalah lembaga yang melaksanakan fungsi pemerintahan yang anggotanya merupakan wakil dari penduduk Nagari berdasarkan keterwakilan unsur masyarakat dengan memperhatikan keterwakilan wilayah dan ditetapkan secara demokratis. Sedangkan Wali Nagari adalah Pejabat Pemerintah Nagari yang mempunyai wewenang, tugas dan kewajiban untuk menyelenggarakan rumah tangga Nagarinya dan melaksanakan tugas dari Pemerintah dan Pemerintah Daerah. Dalam melaksanakan tugasnya, Wali Nagari dibantu oleh perangkat Nagari yang terdiri dari sekretaris Nagari dan perangkat lainnya.

Dalam penyelenggaraan Pemerintahan Nagari, BAMUS merupakan salah satu unsur penting yang perlu dilibatkan dalam setiap pengambilan keputusan yang berkaitan dengan kepentingan masyarakat Nagari. Hal ini dikarenakan BAMUS adalah perwakilan dari masyarakat Nagari yang dipilih secara demokratis oleh masyarakat Nagari. BAMUS merupakan salah satu wujud demokrasi dalam pemerintahan Nagari yang menerima seluruh aspirasi masyarakat dan menyalurkannya untuk kemajuan Nagari. Selain itu, BAMUS juga merupakan lembaga pengawasan terhadap kinerja Wali Nagari. Hal ini dimuat dalam Peraturan Bupati Pesisir Selatan Nomor 26 Tahun 2017 Pasal 36, bahwasannya salah satu fungsi BAMUS adalah melakukan pengawasan terhadap kinerja Wali Nagari.

Kedudukan BAMUS dan Wali Nagari dalam Pemerintahan Nagari adalah setingkat. BAMUS dan Wali Nagari sama-sama dipilih oleh masyarakat secara demokratis melalui musyawarah dan dilantik oleh Bupati.Oleh karena itu, untuk melaksanakan fungsi pengawasan BAMUS, maka BAMUS dan Wali Nagari perlu melakukan koordinasi agar BAMUS dapat mengawasi kinerja Wali Nagari dengan terkoordinir. Dengan begitu, segala informasi yang dibutuhkan oleh BAMUS untuk keperluan pengawasan dapat diperoleh dengan mudah sehingga pengawasan BAMUS pun berjalan dengan lancar.

Menurut (Hasibuan, 2011) koordinasi adalah kegiatan mengarahkan, mengintegrasikan, dan megkoordinasikan unsur-unsur manajemen dan pekerjaanpekerjaan para bawahan dalam mencapai tujuan organisasi. (Hasibuan, 2011) mengatakan bahwa koordinasi perlu dilakukan dalam suatu organisasi untuk mencegah terjadinya kekacauan, percekcokan, dan kekembaran atau kekosongan pekerjaan. Koordinasi merupakan sesuatu yang penting agar semua tindakan di tujukan serta memberikan sumbangannya kepada tujuan umum organisasi. Kemudian (Hasibuan, 2011) membagi koordinasi kedalam dua tipe yaitu koordinasi vertikal dan koordinasi horizontal. Koordinasi vertikal merupakan koordinasi antara atasan dengan bawahan, sedangkan koordinasi horizontal merupakan koordinasi yang dilakukan antar lembaga yang setingkat. Dikarenakan BAMUS 
dan Wali Nagari adalah lembaga setingkat, maka koordinasi yang terjadi antara BAMUS dan Wali Nagari dalam penyelenggaraan Pemerintahan Nagari Muara Sakai adalah koordinasi horizontal.

Kemudian pengertian pengawasan menurut Siagian dalam (Chandra, 2018) merupakan proses pengamatan dari pelaksanaan seluruh kegiatan organisasi untuk menjamin agar semua pekerjaan yang sedang dilaksanakan berjalan sesuai dengan rencana yang telah ditetapkan sebelumnya. Pengawasan dalam penyelenggaraan Pemerintahan daerah bertujuan untuk menjamin agar Pemerintahan diselenggarakan sesuai dengan rencana dan ketentuan peraturan perundang-undangan yang berlaku. Artinya, pengawasan penyelenggaraan Pemerintahan daerah ditujukan untuk mewujudkan Pemerintahan yang bersih (Chandra, 2018).

Pramukti \& Cahyaningsih, (2016), membedakan pengawasan menjadi dua jenis berdasarkan cara pelaksanaannya yaitu : (a) Pengawasan langsung, maksudnya yaitu pengawasannya dilakukan di tempat kegiatan sedang berlangsung, dengan cara mengadakan inspeksi dan pemeriksaan. (b) Pengawasan tidak langsung, yaitu dengan melakukan pemantauan dan melalui laporan baik secara lisan maupun laporan tertulis dari satuan kerja yang bersangkutan, aparat pengawas fungsional, pengawas legislatif, dan pengawas masyarakat.

Berdasarkan observasi awal yang dilakukan, peneliti menemukan bahwa pengawasan yang dilakukan oleh BAMUS Nagari Muara Sakai belum dilakukan secara keseluruhan. Hal ini dikarenakan terdapat beberapa kegiatan Nagari yang tidak diinformasikan kepada BAMUS. Padahal fungsi BAMUS yang tercantum dalam Peraturan Bupati Pesisir Selatan Nomor 26 Tahun 2017 dalam pasal 51 menyebutkan bahwa pengawasan BAMUS terhadap Wali Nagari dilakukan melalui perencanaan kegiatan Pemerintah Nagari, pelaksanaan kegiatan, dan pelaporan penyelenggaraan Pemerintahan Nagari. Artinya, BAMUS Nagari harus mengawasi seluruh kegiatan Nagari mulai dari perencanaan sampai dengan pelaporan. Sementara kegiatan-kegiatan yang tidak diinformasikan kepada BAMUS tidak diketahui oleh BAMUS, akibatnya tidak ada pengawasan BAMUS dalam kegiatan tersebut.

Berdasarkan wawancara awal yang dilakukan dengan ketua BAMUS Nagari Muara
Sakai, ditemukan bahwa salah satu kegiatan yang tidak dilaporkan oleh Wali Nagari kepada BAMUS Nagari Muara Sakai adalah mengenai perubahan anggaran Nagari pada LKPJ tahun 2019. Perubahan anggaran yang dibuat oleh Wali Nagari tersebut tidak dilaporkan kepada BAMUS. Akibatnya dana anggaran yang digunakan dalam kegiatan-kegiatan Nagari selama satu tahun anggaran tersebut tidak diketahui oleh BAMUS rincian keuangannya. LKPJ tahun 2019 tersebut juga belum diserahkan oleh Wali Nagari kepada BAMUS sampai dengan bulan Februari 2021. Hal ini tentu akan berdampak buruk terhadap jalannya pemerintahan Nagari, karena pengawasan BAMUS merupakan salah satu aspek penting dalam Pemerintahan Nagari. Pada hal ini, sebagaimana (Malau \& Akmal, 2020) menyatakan bahwa salah satu persoalan penting dalam penyelenggaraan pemerintahan Nagari berbasis nilai-nilai adat adanya tuntutan keterbukaan dan partisipasi antara lembaga di Nagari agar menjadi lebih demokratis.

Selain itu, pengawasan BAMUS ditujukan untuk menciptakan pemerintahan yang bersih dan menjamin penyelenggaraan pemerintahan berjalan sesuai dengan rencana yang sudah ditetapkan. Apabila tidak ada laporan kepada BAMUS mengenai pelaksanaan kegiatan Nagari, maka BAMUS tidak akan mengetahui mengenai suatu kegiatan yang akan dilaksanakan atau yang sudah selesai dilaksanakan. Akibatnya BAMUS tidak dapat mengawasi kegiatan tersebut, sehingga berpotensi terjadi nya kesalahan-kesalahan yang tidak diinginkan.

Berdasarkan permasalahan yang terjadi, peneliti tertarik untuk melakukan penelitian ini dengan tujuan untuk mendeskripsikan mengenai koordinasi bidang pengawasan antara BAMUS dengan Wali Nagari dalam penyelenggaraan Pemerintahan Nagari Muara Sakai. Penelitian ini perlu dilakukan karena pengawasan dalam penyelenggaraan Pemerintahan Nagari menjadi salah satu hal penting untuk mewujudkan pemerintahan yang bersih. Dan untuk melakukan pengawasan tersebut, perlu adanya koordinasi yang baik antara BAMUS dengan Wali Nagari, sehingga penelitian ini bertujuan untuk mencapai penyelenggaraan pemerintahan Nagari yang baik. 


\section{METODE PENELITIAN}

Metode yang digunakan dalam penelitian ini adalah metode kualitatif, dengan cara mendeskripsikan fenomena yang terjadi dilapangan. Data yang diperoleh berupa katakata tertulis ataupun lisan dari sumber informan dan perilaku yang diamati yang dalam hal ini berkaitan dengan koordinasi pengawasan BAMUS dengan Wali Nagari dalam penyelenggaraan pemerintahan Nagari Muara Sakai.

Penelitian ini dilakukan di Nagari Muara Sakai Kecamatan Pancung Soal Kabupaten Pesisir Selatan, Provinsi Sumatera Barat. Dipilihnya Nagari Muara Sakai sebagai tempat penelitian dikarenakan koordinasi antara BAMUS dengan Wali Nagari di Nagari Muara Sakai inikurang baik dibandingkan dengan daerah lain khususnya dalam kegiatan pengawasan kinerja Wali Nagari oleh BAMUS dalam menyelenggarakan Pemerintahan Nagari.Hal ini dapat dilihat dari pelibatan BAMUS dalam penyelenggaraan Pemerintahan Nagari Muara Sakai belum secara keseluruhan.

Informan dalam penelitian initerdiri dari beberapa unsur penting dalam penyelenggaraan Pemerintahan Nagari yaitu Wali Nagari, BAMUS Nagari, perangkat Nagari, dan tokoh masyarakat Nagari Muara Sakai. Penelitian ini dengan teknik pengumpulan data observasi, wawancara, dan studi dokumentasi. Sumber data utama diperoleh dari data primer dan data sekunder. Pengujian keabsahan data dalam penelitian ini dengan menggunakan teknik triangulasi sumber dan triangulasi metode. Teknik analisis data yang digunakan yaitu: reduksi data, penyajian data, penarikan kesimpulan dan verifikasi.

\section{HASIL DAN PEMBAHASAN}

Koordinasi bidang pengawasan antara BAMUS Nagari dengan Wali Nagari dalam penyelenggaraan Pemerintahan Nagari Muara Sakai dilakukan berdasarkan Peraturan Bupati Pesisir Selatan Nomor 26 Tahun 2017, Pasal 51 Ayat (2), yang terdiri dari: (a) Perencanaan kegiatan Pemerintah Nagari; (b) Pelaksanaan kegiatan; dan (c) Pelaporan penyelenggaraan Pemerintahan Nagari, yaitu sebagai berikut:

\section{Perencanaan Kegiatan Pemerintahan Nagari}

1) Musyawarah Nagari

Kegiatan musyawarah Nagari di Nagari Muara Sakai merupakan kegiatan musyawarah yang dilakukan untuk merencanakan kegiatan
Nagari dalam satu tahun kedepan. Terdapat dua jenis kegiatan musyawarah tahunan di Nagari Muara Sakai, yaitu Musnag (Musyawarah Nagari) dan Musrenbang (Musyawarah Perencanaan Pembangunan). Musnag dan musrenbang di Nagari Muara Sakai dilaksanakan satu kali dalam satu tahun dan biasanya dilaksanakan di akhir tahun untuk membahas rancangan kegiatan Nagari untuk satu tahun yang akan datang.

Musnag dan Musrenbang merupakan kegiatan musyawarah yang tidak dapat dipisahkan satu sama lain, keduanya saling berhubungan. Berdasarkan data wawancara, pelaksanaan Musnag di Nagari Muara Sakai dilakukan sebelum Musrenbang. Musnag hanya dihadiri oleh beberapa orang masyarakat yang mewakili masing-masing bidang dalam kehidupan masyarakat Nagari, sedangkan Musrenbang boleh dihadiri oleh seluruh masyarakat Nagari.

Musrenbang merupakan kegiatan musyawarah untuk melakukan perencanaan pembangunan di Nagari yang mengikutsertakan seluruh masyarakat Nagari sebagai partisipan dalam musyawarah tersebut. Musrenbang Nagari Muara Sakai dilakukan untuk memastikan agar pembangunan yang akan dilaksanakan di Nagari Muara Sakai dapat terencana dengan baik untuk meminimalisir kegagalan sehingga hasil yang diperoleh dari pelaksanaan pembangunannya nanti menjadi lebih maksimal. Dengan begitu, maka dapat menghasilkan pembangunan yang memberikan manfaat kepada masyarakat dan lebih tepat sasaran sesuai dengan kebutuhan masyarakat. BAMUS Nagari sebagai perwakilan dari masyarakat Nagari juga dapat memberikan usulan program kerja sebagai bentuk penyaluran dari aspirasi masyarakat terkait program yang akan dilaksanakan di Nagari Muara Sakai. Hal ini sesuai dengan fungsi BAMUS berdasarkan Peraturan Bupati Pesisir Selatan Nomor 26 Tahun 2017 Pasal 36 bagian (b) yaitu menampung dan menyalurkan aspirasi masyarakat Nagari.

Pengawasan yang dilakukan oleh BAMUS Nagari Muara Sakai melalui kegiatan musnag dan musrenbang merupakan salah satu bentuk pengawasan dalam perencanaan kegiatan pemerintahan Nagari. Perencanaan kegiatan Pemerintahan Nagari merupakan tahap awal dalam penyelenggaraan Pemerintahan Nagari. Perencanaan kegiatan pemerintahan Nagari tercantum dalam Perda Kabupaten Pessel 
Nomor 8 Tahun 2007, Pasal 85 menyebutkan bahwa “...dalam rangka penyelenggaraan Pemerintahan Nagari disusun perencanaan pembangunan Nagari sebagai satu kesatuan dalam sistem perencanaan pembangunan daerah Kabupaten..." Hal ini berarti bahwa dalam perencanaan kegiatan Pemerintahan Nagari perlu diawasi oleh BAMUS agar rencana-rencana kegiatan yang ditetapkan nantinya sesuai dengan apa yang diharapkan.

Dalam kegiatan musyawarah Nagari, BAMUS menghadiri langsung dan melihat secara langsung kegiatan tersebut. BAMUS juga ikut terlibat dalam perencanaan program kerja Nagari yang dibahas dalam kegiatan Musnag dan Musrenbang. Berdasarkan hal tersebut, maka pengawasan yang dilakukan oleh BAMUS Nagari terhadap Wali Nagari Muara Sakai melalui kegiatan musnag dan musrenbang ini termasuk kedalam pengawasan langsung. Hal ini berdasarkan pada teori pengawasan yang dikemukakan oleh (Pramukti \& Cahyaningsih, 2016) yang mengatakan bahwa pengawasan langsung adalah pengawasan yang dilakukan langsung ditempat kegiatan sedang berlangsung. BAMUS secara langsung mengawasi jalannya kegiatan Musnag dan Musrenbang, apabila terjadi penyelewengan atau program kerja yang ditetapkan tidak sesuai dengan kebutuhan masyarakat, BAMUS dapat memberikan komentar atau masukan agar setiap program yang dilaksanakan di Nagari mengutamakan kepentingan masyarakat dan sesuai dengan kebutuhan masyarakat Nagari.

Musyawarah Nagari Muara Sakai tahun 2020 dilaksanakan pada tanggal 20 Oktober 2020 sedangkan Musrenbang dilaksanakan pada tanggal 21 Desember 2020. Dalam kegiatan Musyawarahh Nagari Muara Sakai, masyarakat yang mewakili bidang-bidang tertentu menyampaikan usulan-usulan untuk dijadikan sebagai program Nagari Muara Sakai yang nantinya akan dilaksanakan menggunakan anggaran Nagari. Kemudian program-program yang diusulkan oleh masyarakat pada saat Musnag di bahas kembali dalam Musrenbang untuk dimusyawarahkan secara bersama. Program tersebut diputuskan berdasarkan keputusan bersama, yang dilihat dari urgensinya. Semua unsur terkait yang menghadiri kegiatan Musrenbang dapat melihat secara langsung program kerja Nagari yang sudah dirancang sedemikian rupa untuk dijalankan selama satu tahun kedepan. Dengan begitu penyelenggaraan pemerintahan Nagari menjadi lebih terbuka kepada masyarakat, masyarakat mengetahui anggaran Nagari digunakan untuk kegiatan apa saja nantinya.

Berikut adalah alur mekanisme musyawarah Nagari di Muara Sakai yang di analisis berdasarkan temuan penelitian.

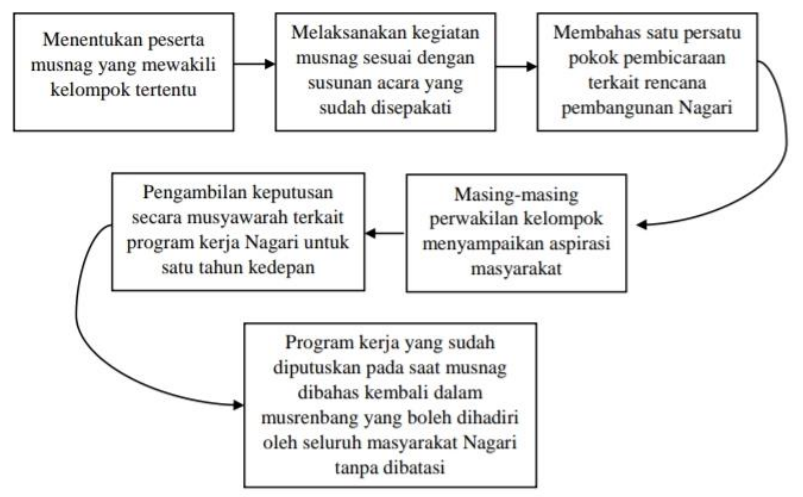

Gambar 1. Mekanisme Musyawarah Nagari (Sumber: Hasil Olahan Penulis, 2021)

2) Rapat koordinasi

Berdasarkan data wawancara, rapat koordinasi di Nagari Muara Sakai dilakukan untuk mempersiapkan kegiatan Nagari yang akan dilaksanakan di Nagari Muara Sakai. Dalam rapat koordinasi akan dibahas beberapa hal mengenai kegiatan yang akan dilaksanakan tersebut. Rapat koordinasi juga dilakukan untuk mempertimbangkan beberapa hal penting sebelum dilakukannya sebuah pembangunan. Misalnya dalam tiga bulan kedepan akan dilakukan beberapa pembangunan di Nagari Muara Sakai seperti pengerasan jalan, pembangunan jamban keluarga, dan pembangunan stadion mini. Jika ketiga pembangunan ini tidak dapat terlaksana semuanya, maka perlu pertimbangan yang matang untuk menentukan mana yang lebih penting dan lebih membutuhkan. Hal ini dibahas didalam rapat koordinasi untuk mencapai ke-efektifan dalam penggunaan anggaran.

Rapat koordinasi yang dilakukan di Pemerintahan Nagari Muara Sakai melibatkan pemerintah Nagari dan semua unsur yang terlibat dalam penyelenggaraan pemerintahan Nagari termasuk unsur BAMUS. Dalam rapat koordinasi disampaikan mengenai laporan tentang program/kegiatan yang akan, sedang, atau sudah dilakukan dan selanjutnya dibahas atau didiskusikan secara bersama mengenai jadwal pelaksanaan, mekanisme pelaksanaan, 
dan juga kendala dalam pelaksanaan disertai dengan upaya untuk mengatasinya.

Berdasarkan hasil penelitian, dalam rapat koordinasi yang dilakukan di Nagari Muara Sakai, BAMUS Nagari dapat menyampaikan pendapat dan usulan dari masyarakat terkait pelaksanaan kegiatan. BAMUS Nagari mengawasi secara langsung perencanaan dan persiapan pelaksanaan kegiatan yang akan dilaksanakan dalam waktu dekat oleh Wali Nagari beserta perangkat. Dengan begitu BAMUS dapat melihat dan mengawasi secara langsung jika terjadi kesalahan dalam persiapan untuk pelaksanaan kegiatan tersebut.

Selain untuk mengkomunikasikan mengenai kegiatan-kegiatan yang akan dilakukan di Nagari Muara Sakai, rapat koordinasi juga dilakukan untuk menyelesaikan suatu perkara apabila terjadi masalah atau ketimpangan antara Wali Nagari dan BAMUS Nagari sebagai dua unsur yang saling berkaitan dalam penyelenggaraan Pemerintahan Nagari. Hal ini dilakukan untuk menemukan solusi atau jalan keluar dari permasalahan yang ada. Seluruh unsur yang hadir dalam rapat koordinasi ikut bermusyawarah untuk menyelesaikan masalah yang ada agar masalah tidak berlarut-larut. Unsur yang ada saling bekerjasama untuk mencarikan solusi dari permasalahan yang sedang terjadi.

Secara teoritis, rapat koordinasi ini termasuk kedalam pengawasan langsung, hal ini berdasarkan teori pengawasan yang dikemukakan oleh (Pramukti \& Cahyaningsih, 2016). BAMUS menghadiri langsung rapat koordinasi yang dilaksanakan oleh Wali Nagari untuk membahas mengenai kegiatan yang akan dilaksanakan dalam waktu dekat di Nagari Muara Sakai. Menurut (Pramukti \& Cahyaningsih, 2016), pengawasan langsung adalah pengawasan yang dilakukan langsung ditempat kegiatan, yaitu dengan mengadakan inspeksi dan pemeriksaan.

Berdasarkan hasil wawancara yang dilakukan dengan salah satu perangkat Nagari Muara Sakai, rapat koordinasi di Nagari Muara Sakai tidak dilakukan secara rutin. Rapat koordinasi hanya dilakukan saat dirasa ada hal penting yang perlu dibahas. Padahal rapat koordinasi yang dilakukan secara rutin sangat membantu kelancaran jalannya pemerintahan. Dengan dilakukannya rapat koordinasi secara berkala, seluruh kegiatan yang dilaksanakan dalam tiga bulan terakhir oleh Wali Nagari dapat dilaporkan kepada BAMUS Nagari dan kegiatan yang akan dilaksanakan kedepannya dapat dipersiapkan secara matang dan dibahas lebih mendetail.

Pada tahun 2020, rapat koordinasi di Nagari Muara Sakai hanya dilakukan sebanyak 2 kali. Hal ini tidak sesuai dengan teori pengawasan langsung yang dikemukakan oleh Hanafi dalam (Purwadi, 2017). Menurut Hanafi dalam (Purwadi, 2017), pengawasan langsung adalah inspeksi teratur yang dilakukan secara berkala dengan mengamati kegiatan yang dilakukan. Pengawasan dilakukan secara berkesinambungan dan dalam waktu berkala agar setiap kegiatan yang dilaksanakan tidak terlewat dari pengawasan sehingga semua kegiatan dapat berjalan dengan lancar dan sesuai dengan apa yang diharapkan.

Berdasarkan hal tersebut, peneliti menilai bahwa pengawasan BAMUS terhadap kinerja Wali Nagari melalui rapat koordinasi belum berjalan dengan cukup baik karena rapat koordinasi yang dilakukan di Nagari Muara Sakai tidak rutin dan tidak berkala.

\section{Pelaksanaan Kegiatan}

1) Komunikasi antara BAMUS dan Wali Nagari

Berdasarkan temuan dilapangan, peneliti menilai bahwa komunikasi antara BAMUS dan Wali Nagari Muara Sakai belum berjalan dengan cukup baik. Kegiatan yang akan dilaksanakan di Nagari Muara Sakai disampaikan secara lisan kepada BAMUS melalui ketua BAMUS oleh Wali Nagari selaku penyelenggara Pemerintahan Nagari Muara Sakai. Namun, Wali Nagari tidak mengkomunikasikan seluruh kegiatan Nagari kepada BAMUS Nagari, dalam beberapa kegiatan terkadang Wali Nagari tidak mengkomunikasikannya dengan BAMUS mengenai pelaksanaan kegiatan tersebut.

Salah satu kegiatan yang tidak dikomunikasikan kepada BAMUS yaitu mengenai pembangunan parit miring yang dilakukan di Nagari Muara Sakai. Hal ini berdasarkan hasil wawancara yang dilakukan dengan salah satu perangkat Nagari Muara Sakai. Peneliti menemukan bahwa terdapat masalah dalam pembangunan parit miring di Nagari Muara Sakai. Pada awal perencanaannya, parit miring dibangun di lokasi Lubuk Gedang yang merupakan salah satu kampung di Nagari Muara Sakai. Namun dikarenakan beberapa hal, anggaran yang sudah dianggarkan untuk pembangunan parit miring 
di Lubuk Gedang tersebut dialihkan oleh Wali Nagari untuk pembangunan parit miring dilokasi yang berbeda. Hal tersebut dilakukan oleh Wali Nagari tanpa mengkomunikasikan nya terlebih dahulu dengan BAMUS Nagari. Akibatnya BAMUS Nagari tidak mengetahui bahwasannya pembangunan parit miring yang rencananya dilaksanakan di Lubuk Gedang dialihkan ke lokasi lain. Sehingga apabila masyarakat bertanya kepada BAMUS, terjadi salah komunikasi antara BAMUS dengan masyarakat karena BAMUS tidak mengetahui pengalihan pembangunan tersebut.

Komunikasi merupakan hal yang sangat mendasar dalam berbagai macam aktivitas yang dilakukan oleh manusia, termasuk dalam koordinasi pengawasan. Hal tersebut dikarenakan kegiatan pengawasan membutuhkan komunikasi antara pihak yang mengawasi dan pihak yang diawasi. Dalam melakukan pengawasan terhadap Wali Nagari, BAMUS berkomunikasi dengan Wali Nagari maupun dengan perangkat Nagari untuk mengetahui mengenai kegiatan-kegiatan yang akan dilaksanakan, yang sedang dilaksanakan, maupun yang sudah dilaksanakan di Nagari Muara Sakai.

Komunikasi antara BAMUS dengan Wali Nagari termasuk ke dalam pengawasan langung. Seperti konsep pengawasan langsung yang dikemukakan oleh (Pramukti \& Cahyaningsih, 2016) bahwasannya pengawasan langsung merupakan pengawasan yang digelar di tempat kegiatan berlangsung. Komunikasi antara BAMUS Nagari dengan Wali Nagari ini dilakukan secara langsung saat kegiatan sedang berlangsung. Komunikasi dilakukan untuk membahas mengenai keberlangsungan kegiatan Nagari, baik itu mengenai kendala yang sedang dihadapi dan cara mengatasinya, atau mengenai progres kegiatan tersebut. Dengan begitu, BAMUS Nagari mengetahui setiap hal mengenai kegiatan tersebut sehingga tidak terjadi kesalahpahaman antara keduanya dan pelaksanaan kegiatan pun berjalan dengan baik dengan pengawasan yang baik pula.

Berdasarkan hal tersebut, berarti koordinasi pengawasan BAMUS Nagari terhadap Wali Nagari Muara Sakai dalam pelaksanaan kegiatan Nagari yang dilakukan melalui komunikasi antara BAMUS dan Wali Nagari Muara Sakai belum cukup baik karena terdapat beberapa kegiatan yang tidak dikomunikasikan kepada BAMUS. Hal tersebut akan berdampak pada kelancaran pelaksanaan kegiatan Nagari karena BAMUS Nagari tidak mengawasi secara keseluruhan kegiatan yang dilaksanakan di Nagari Muara Sakai. Sehingga nantinya juga akan berdampak buruk terhadap program pembangunan Nagari Muara Sakai dan tentu bagi masyarakat Nagari juga. Hal ini terjadi karena jika BAMUS tidak mengetahui suatu kegiatan yang sedang berlangsung atau kegiatan yang akan dilaksanakan di Nagari Muara Sakai maka BAMUS tidak dapat melakukan pengawasan terhadap kegiatan tersebut karena BAMUS tidak mendapatkan informasi mengenai kegiatan tersebut, akibatnya pengawasan tidak dilakukan sehingga kegiatan yang dilaksanakan tersebut bisa saja tidak berjalan sesuai dengan rencana yang sudah ditetapkan dan tidak sesuai dengan apa yang diinginkan oleh masyarakat.

Berikut adalah alur komunikasi antara Pemerintah Nagari dengan BAMUS Nagari Muara Sakai berdasarkan analisis dari temuan penelitian.

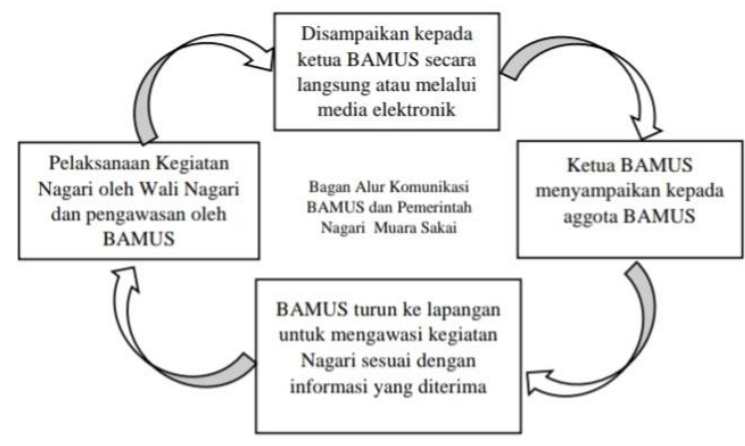

\section{Gambar 2. Alur komunikasi Pemerintah Nagari dengan BAMUS Nagari}

(Sumber: Hasil Olahan Penulis, 2021)

\section{2) BAMUS Turun langsung ke lapangan}

Berdasarkan temuan peneliti, BAMUS Nagari Muara Sakai turun langsung ke lokasi kegiatan untuk memantau apakah kegiatan yang dilaksanakan sesuai dengan perencanaan atau tidak. Sehingga apabila terjadi kesalahan atau terdapat hambatan dalam pelaksanaan kegiatan, dapat segera diatasi secara bersama-sama agar kegiatan tetap berjalan dengan baik. BAMUS Nagari Muara Sakai mengawasi secara langsung kegiatan yang dilaksanakan di Nagari Muara Sakai. Salah satu contohnya seperti pembangunan stadion mini yang dilaksanakan di Nagari Muara Sakai, BAMUS langsung datang ke lokasi pembangunan stadion mini tersebut untuk melihat keberlangsungan pelaksanaan pembangunan sekaligus untuk mengawasi perkembangan pembangunan 
tersebut. BAMUS melihat apakah pembangunan berjalan sesuai dengan apa yang sudah direncanakan sebelumnya atau tidak, kemudian BAMUS juga melihat apakah penggunaan anggaran oleh Wali Nagari sesuai dengan Rencana Anggaran Belanja yang sudah dibuat atau tidak. Berdasarkan hal tersebut, maka koordinasi pengawasan BAMUS dengan Wali Nagari dengan cara BAMUS turun langsung kelapangan termasuk kedalam pengawasan langsung.

Pramukti \& Cahyaningsih, (2016), mengemukakan bahwa pengawasan langsung adalah pengawasan yang dilakukan langsung ditempat kegiatan, yaitu dengan mengadakan inspeksi dan pemeriksaan. Di Nagari Muara Sakai, BAMUS mengawasi langsung setiap kegiatan yang dilaksanakan di Nagari Muara Sakai dengan cara memeriksa beberapa hal yang menjadi poin penting dalam kegiatan tersebut seperti progres kegiatan, anggaran yang digunakan, ketersediaan sumber daya, dan lain sebagainya. Dengan mengawasi secara langsung seperti ini, kegiatan yang dilaksanakan menjadi lebih teratur dan terstruktur sehingga dapat berjalan sesuai dengan apa yang sudah direncanakan. Hal ini memungkinkan tujuan dari pelaksanaan kegiatan dapat tercapai dengan cukup baik.

\section{Pelaporan Penyelenggaraan Pemerintahan Nagari}

Berdasarkan temuan penelitian, koordinasi bidang pengawasan antara BAMUS Nagari dengan Wali Nagari dalam pelaporan penyelenggaraan Pemerintahan Nagari Muara Sakai dilakukan melalui laporan pertanggungjawaban yang diserahkan oleh Wali Nagari kepada BAMUS Nagari. Wali Nagari menyampaikan laporan kepada BAMUS Nagari setiap tiga bulan sekali. Kegiatankegiatan yang dilaksanakan dalam tiga bulan tersebut dilaporkan secara umum dan disampaikan kepada BAMUS untuk kemudian diamati apakah kegiatan yang dilaksanakan oleh Wali Nagari tersebut sesuai dengan rencana awal atau tidak, dan apakah mencapai tujuannya atau tidak.

Selain itu, laporan juga disampaikan oleh Wali Nagari Muara Sakai kepada BAMUS setiap satu tahun anggaran. Semua kegiatankegiatan yang dilaksanakan di Nagari Muara Sakai dalam satu tahun terakhir dilaporkan kepada BAMUS dalam bentuk LKPJ. Hal ini dimuat dalam Perda Kabupaten Pesisir Selatan
Nomor 28 Tahun 2007, dalam Pasal 13 Ayat (4) yang menyebutkan bahwa "....Laporan Keterangan Pertanggungjawaban kepada BAMUS Nagari sebagaimana dimaksud pada ayat (2) disampaikan 1 (satu) kali dalam 1 (satu) tahun dalam musyawarah BAMUS Nagari..." Jadi, seluruh kegiatan penyelenggaraan pemerintahan Nagari dalam satu tahun terkahir dilaporkan kepada BAMUS Nagari secara rinci dan detail dalam bentuk LKPJ.

Namun hal ini berbeda dengan dokumen yang peneliti temukan di Nagari Muara Sakai, peneliti menemukan bahwa pada tahun 2020 terdapat beberapa kali surat teguran yang disampaikan oleh BAMUS kepada Wali Nagari terkait Laporan akhir tahun yang tidak sesuai dengan kenyataannya. Surat teguran pertama disampaikan kepada Wali Nagari pada tanggal 09 Juni 2020, dan surat teguran kedua disampaikan pada tanggal 27 Juni 2020. Dalam surat teguran ini BAMUS menyampaikan kepada Wali Nagari agar segera menyelesaikan beberapa hal meliputi: (1) penandatanganan LKPJ 2019; (2) APB perubahan 2019; dan (3) kegiatan perubahan 2019 yang belum dilaksanakan.

BAMUS Nagari Muara Sakai mengeluarkan surat teguran tersebut karena Wali Nagari belum menyerahkan LKPJ tahun 2019 kepada BAMUS sampai dengan Februari 2021. Kurang lebih satu tahun keterlambatan Wali Nagari dalam menyampaikan Laporan tahunan kepada BAMUS. Seharusnya LKPJ harus diserahkan dan ditandatangani oleh BAMUS di akhir tahun dan selambat-lambatnya pada awal bulan di tahun berikutnya, sebelum LKPJ tersebut dilaporkan ke Pemerintah Daerah tingkat Kabupaten.

Selain keterlambatan penyerahan LKPJ, perubahan yang dibuat pada anggaran Nagari Tahun 2019 juga tidak diketahui oleh BAMUS Nagari dan tidak dilaporkan kepada BAMUS Nagari. Menurut (Faisal \& Failin, 2019), surat teguran diberikan untuk memanggil pihak terkait kemudian meminta keterangan lebih lanjut terhadap permasalahan yang timbul di dalam Pemerintahan Nagari. Dalam hal ini, surat teguran yang diberikan oleh BAMUS Nagari Muara Sakai bertujuan agar Wali Nagari segera melaporkan LKPJ nya dan menjelaskan rincian mengenai perubahan anggaran yang dibuat di LKPJ tersebut.

LKPJ termasuk kedalam pengawasan tidak langsung. Hal ini berdasarkan konsep pengawasan tidak langsung yang dikemukakan 
oleh (Pramukti \& Cahyaningsih, 2016) yang mengatakan bahwa pengawasan tidak langsung yaitu pengawasan yang dilakukan dengan melakukan pemantauan dan mengkaji laporan yang diberikan oleh unsur terkait kepada lembaga pengawasan, aparat pengawas fungsional, pengawas legislatif, ataupun pengawas masyarakat. Dalam hal ini, BAMUS Nagari Muara Sakai tidak mengawasi kinerja Wali Nagari secara langsung namun melalui laporan yang disampaikan oleh Wali Nagari kepada BAMUS baik itu laporan persemester maupun laporan selama satu tahun anggaran.

Berdasarkan pemaparan diatas, penulis menilai bahwa pengawasan tidak langsung yang dilakukan oleh BAMUS Nagari terhadap Wali Nagari melalui laporan tertulis belum berjalan dengan cukup baik. LKPJ yang seharusya sudah diserahkan oleh Wali Nagari di akhir tahun 2019 dan paling lambat di awal tahun 2020 namun sampai Februari 2021 masih belum diserahkan kepada BAMUS. Hal ini membuktikan bahwa Wali Nagari belum mampu mempertanggungjawabkan dengan baik kegiatan-kegiatan yang dilaksanakan di Nagari Muara Sakai selama satu tahun anggaran tersebut (tahun anggaran 2019).

Berdasarkan deskripsi data diatas, dapat dipahami bahwa koordinasi bidang pengawasan antara BAMUS Nagari dengan Wali Nagari dalam penyelenggaraan Pemerintahan Nagari Muara Sakai belum berjalan dengan cukup baik. Hal ini disebabkan oleh beberapa faktor yang menghambat jalannya koordinasi pengawasan BAMUS dengan Wali Nagari Muara Sakai, yaitu sebagai berikut:

\section{1) Faktor Komunikasi}

Berdasarkan hasil penelitian, komunikasi antara BAMUS Nagari dan Wali Nagari dalam penyelenggaraan Pemerintahan Nagari Muara Sakai belum berjalan dengan cukup baik. Komunikasi yang kurang baik ini dapat dilihat dari beberapa kegiatan Nagari yang tidak dikomunikasikan oleh Wali Nagari kepada BAMUS Nagari. Hal ini mengakibatkan kegiatan Nagari tersebut tidak terawasi secara keseluruhan oleh BAMUS. Salah satunya yaitu mengenai perubahan lokasi pembangunan parit miring di Nagari Muara Sakai yang tidak di informasikan oleh Wali Nagari kepada BAMUS Nagari, akibatnya pembangunan parit miring tersebut tidak diawasi oleh BAMUS sebagai wakil dari masyarakat.
BAMUS Nagari merupakan lembaga pengawas terhadap kinerja Wali Nagari. Apabila komunikasi antara keduanya tidak berjalan dengan baik, maka hal ini juga akan berpengaruh terhadap pengawasannya karena komunikasi adalah salah satu inti dari koordinasi bidang pengawasan. Sebagaimana Hasibuan, (2011) menyatakan bahwa komunikasi merupakan salah satu hal yang sangat penting dalam koordinasi, karena sejumlah unsur dalam organisasi akan dapat dikoordinasikan dengan adanya komunikasi. Begitupun dalam penyelenggaraan Pemerintahan Nagari Muara Sakai, komunikasi antara BAMUS dan Wali Nagari sangat dibutuhkan karena keduanya merupakan unsur penting dalam penyelenggaraan Pemerintahan Nagari. Berdasarkan hal tersebut, peneliti menilai bahwa komunikasi yang kurang baik antara BAMUS Nagari dan Wali Nagari Muara Sakai menjadi salah satu faktor penghambat pengawasan BAMUS Nagari terhadap Wali Nagari dalam Penyelenggaraan Pemerintahan di Nagari Muara Sakai.

\section{2) Kurangnya Gagasan BAMUS}

Berdasarkan temuan dilapangan, BAMUS Nagari Muara Sakai terdiri dari lima unsur yang berbeda yang terdiri dari unsur Ninik Mamak, Alim Ulama, Cadiak Pandai, Bundo Kanduang dan usur Pemuda. Namun, unsur-unsur yang mewakili BAMUS tersebut belum menjalankan tugas nya sesuai dengan tupoksi nya masingmasing. Hal ini dapat dilihat dari pengawasan yang dilakukan oleh BAMUS di beberapa kegiatan Nagari. BAMUS tidak sepenuhnya dalam menjalankan tupoksinya sehingga sering timbul permasalahan ditengah masyarakat karena kegiatan yang dilaksanakan oleh pemerintah Nagari ada yang tidak sesuai dan menyimpang dari aturan yang ada, sementara pengawasan dari BAMUS tidak dilakukan secara menyeluruh. Seharusnya BAMUS yang terdiri dari lima unsur perwakilan masyarakat mampu melakukan pembagian kerja untuk melakukan pengawasan kegiatan Nagari sesuai dengan bidangnya.

Misalnya BAMUS dari unsur pemuda dapat melakukan pengawaan terhadap kegiatan dibidang kepemudaan seperti kegiatan olahraga, wirid remaja, dan lain sebagainya. Begitupun dengan unsur BAMUS lainnya dapat melakukan pengawasan dan berkoordinasi dengan pelaksana kegiatan sesuai dengan bidangnya masing-masing. Dengan begitu 
maka kegiatan-kegiatan yang dilaksanakan di Nagari Muara Sakai dapat diawasi sepenuhnya oleh BAMUS tanpa mengandalkan salah satu unsur saja.

Menurut (Hasibuan, 2011), pembagian kerja bertujuan agar supaya suatu organisasi dapat mencapai tujuanny dengan baik. Dengan prinsip pembagian kerja ini diharapkan dapat mewujudkan tujuan suatu organisasi. Pembagian kerja merupakan perincian pekerjaan masing-masing anggota organisasi agar setiap individu bertanggung jawab dalam melaksanakan kegiatan dan tugasnya masingmasing. Namun, yang terjadi di Nagari Muara Sakai berbeda dengan apa yang dikemukakan oleh Hasibuan, BAMUS Nagari melakukan pengawasan terhadap kinerja Wali Nagari dalam satu kesatuan yang kaku tanpa adanya prinsip pembagian kerja. Akibatnya, pengawasan yang dilakukan hanya tertumpu pada satu orang saja. BAMUS dituntut harus mempunyai gagasan dalam melaksanakan pengawasan terhadap kinerja Wali Nagari. Dalam hal ini kurangya gagasan anggota BAMUS dapat mempengaruhi pengawasan yang di lakukan oleh BAMUS tersebut.

3) Kurangnya Kesatuan Tindakan antara BAMUS dengan Wali Nagari

Adanya ketidak sinkron-an antara BAMUS dan Wali Nagari dalam beberapa kegiatan yang dilaksanakan di Nagari Muara Sakai Kecamatan Pancung Soal menjadi salah satu penghambat pengawasan yang dilakukan oleh BAMUS Nagari terhadap Wali Nagari. Perbedaan pendapat merupakan persoalan yang wajar dan tidak bisa dipungkiri bahwa setiap manusia memiliki pendapat yang berbeda. Namun dari hasil temuan peneliti, perbedaan pendapat antara Wali Nagari dan BAMUS Nagari Muara Sakai terlihat sangat jelas. Keduanya memiliki pendapat yang kuat dan saling mempertahankan apa yang menurut mereka benar. Hal ini tentu akan sangat mempengaruhi jalannya koordinasi bidang pengawasan antara BAMUS dan Wali Nagari. Jika keduanya sama-sama keras dengan pendapat mereka, tentu tidak akan menemukan jalan tengah nya sehingga tidak dapat diperoleh keputusan akhir. Menurut (Junaidi, 2020), perbedaan pandangan antara BAMUS dan Wali Nagari akan menjadi hambatan dalam hubungan antara keduanya, karena dalam setiap pengambilan kebijakan oleh pemerintah Nagari harus dikonsultasikan dengan BAMUS dan tanpa persetujuan BAMUS kebijakan Nagari tidak dapat dikeluarkan.

Menurut (Hasibuan, 2011), pada dasarnya dalam koordinasi perlu adanya kesadaran bagi setiap anggota organisasi untuk saling beradaptasi dan menyesuaikan diri dengan yang lain agar tidak berjalan sendiri-sendiri. Oleh karena itu konsep kesatuan tindakan adalah pokok dari koordinasi itu sendiri. Namun, yang terjadi di Nagari Muara Sakai, BAMUS dan Wali Nagari nya seringkali tidak sinkron tindakannya di beberapa kegiatan yang dilaksanakan. Hal ini akan berpengaruh terhadap jalannya koordinasi dan juga berdampak pada pengawasan yang dilakukan oleh BAMUS. Selain itu, hal ini juga akan berpengaruh terhadap kegiatan yang akan dilaksanakan di Nagari Muara Sakai. Dikarenakan adanya ketidak sinkron-an antara BAMUS dan Wali Nagari dalam penyelenggaraan Pemerintahan Nagari, maka kegiatan-kegiatan yang sudah direncanakan sebelumnya akan berantakan dan tidak berjalan sesuai dengan rencana sehingga tujuan yang telah ditetapkan tidak dapat tercapai dengan baik.

4) Kurangnya Transparansi Wali Nagari

Berdasarkan data wawancara, Wali Nagari kurang terbuka kepada BAMUS mengenai beberapa kegiatan yang dilaksanakan di Nagari Muara Sakai. Hal ini menjadi salah satu hambatan bagi pengawasan yang dilakukan oleh BAMUS Nagari. Kurang terbukanya Wali Nagari terhadap beberapa kegiatan menyebabkan pengawasan yang dilakukan oleh BAMUS tidak menyeluruh, sehingga kegiatankegiatan yang tidak terawasi oleh BAMUS Nagari berpotensi tidak berjalan dengan baik sesuai dengan perencanaan karena pengawasan BAMUS Nagari merupakan salah satu aspek penting dalam penyelenggaraan Pemerintahan Nagari. BAMUS merupakan wakil masyarakat sebagai pengawas kinerja Wali Nagari, seperti yang tercantum salam Peraturan Bupati Pesisir Selatan Nomor 26 Tahun 2017, dalam Pasal 36 bagian (c) yang menyebutkan bahwa "BAMUS Nagari mempunyai fungsi melakukan pengawasan kinerja Wali Nagari”. Berarti seluruh kegiatan yang dilaksanakan di Nagari Muara Sakai wajib diketahui oleh BAMUS.

BAMUS memiliki kewajiban untuk memperoleh informasi setiap kegiatan penyelenggaraan Pemerintahan oleh Wali Nagari. Menurut Mardiasmo yang dikutip 
dalam (Rahmanurrasjid, 2008), transparansi merupakan suatu bentuk keterbukaan pemerintah dalam menyampaikan informasi terkait aktivitas pengelolaan sumber daya publik kepada berbagai unsur yang membutuhkan informasi tersebut. Pemerintah wajib memberikan informasi keuangan dan yang lainnya untuk digunakan dalam pengambilan keputusan oleh pihak-pihak yang memiliki kepentingan.

Ketidakterbukaan Wali Nagari terhadap BAMUS di beberapa kegiatan Nagari menimbulkan spekulasi masyarakat bahwasannya ada yang disembunyikan oleh Wali Nagari dalam pelaksanaan kegiatan tersebut. Apabila Wali Nagari tidak transparan dengan kegiatan-kegiatan yang ada, maka koordinaaansi BAMUS dan Wali Nagari akan terhambat dan hal tersebut menyebabkan pengawasan yang dilakukan oleh BAMUS tidak menyeluruh sehingga terdapat beberapa kegiatan Nagari tidak terawasi dengan cukup baik oleh BAMUS.

\section{PENUTUP}

Koordinasi bidang pengawasan antara BAMUS Nagari dengan Wali Nagari dalam penyelenggaraan Pemerintahan Nagari Muara Sakai dalam pelaksanaannya berdasarkan Perbup Pessel No. 26 Tahun 2017 Pasal 51 Ayat (2) yaitu melalui perencanaan, pelaksanaan kegiatan, dan pelaporan. Pengawasan BAMUS yang dilakukan melalui perencanaan kegiatan Pemerintahan Nagari dan pelaksanaan kegiatan termasuk kedalam pengawasan langsung yang meliputi: musyawarah Nagari, rapat koordinasi, komunikasi antara BAMUS dan Wali Nagari, dan BAMUS turun langsung kelokasi kegiatan Nagari. Sedangkan pengawasan BAMUS yang dilakukan melalui pelaporan penyelenggaraan Pemerintahan Nagari merupakan pengawasan tidak langsung yang dilakukan melalui laporan pertanggungjawaban Wali Nagari kepada BAMUS Nagari.

Koordinasi bidang pengawasan antara BAMUS Nagari dengan Wali Nagari dalam penyelenggaraan Pemerintahan Nagari Muara Sakai belum dilakukan dengan cukup baik. Hal ini disebabkan karena terdapat beberapa faktor yang menghambat jalannya koordinasi bidang pengawasan antara BAMUS dengan Wali Nagari yaitu: komunikasi yang kurang baik antara BAMUS dengan Wali Nagari, kurangnya kesatuan tindakan antara BAMUS dengan Wali Nagari dalam beberapa kegiatan, kurangnya gagasan BAMUS terhadap tupoksi masingmasing unsur, dan kurangnya transparansi Wali Nagari terhadap beberapa kegiatan Nagari. Berdasarkan hasil penelitian, penulis menyarankan sebaiknya BAMUS dan Wali Nagari meningkatkan lagi keharmonisan hubungan antara keduanya agar komunikasi nya berjalan dengan lancar. Dengan begitu koordinasi antara keduanya juga akan berjalan dengan baik, sehingga pengawasan BAMUS dapat terlaksana secara keseluruhan.

\section{DAFTAR PUSTAKA}

Chandra, M. J. A. (2018). Kewenangan Bank Indonesia dalam Pengaturan dan Pengawasan Di Indonesia Setelah Terbitnya Undang-Undang No. 21 Tahun 2011 Tentang OJK. Bengkulu: CV. Zigie Utama.

Faisal, \& Failin. (2019). Pelaksanaan Fungsi Pengawasan Badan Musyawarah Nagari dalam Mengawasi Pemerintahan Di Nagari Canduang Koto Laweh dan Nagari Lasi Kecamatan Canduang Kabupaten Agam. Ensiklopedia Social Review, 1(2), 156-163. https://doi.org/https://doi.org/10.33559/e sr.v1i2.252

Hasibuan, M. S. . (2011). Manajemen: Dasar, Pengertian, dan Masalah. Jakarta: PT. Bumi Aksara.

Junaidi, T. (2020). Peran Badan Musyawarah Nagari Sungai Sariak sebagai Pengawas Penggunaan Anggaran yang Bersumber dari Dana Desa. UNES Law Review, 2(2), 178-189.

https://doi.org/https://doi.org/10.31933/u nesrev.v2i2.112

M Faiz Satrianegara. (2009). Organisasi dan Manajemen Pelayanan Kesehatan Serta Kebidanan. Jakarta: Salemba Madika.

Malau, H., \& Akmal, A. D. (2020). Synergy of Indigenous Values With Law Number 6 of 2014 Concerning Village: Study on Nagari Kapau Government In West Sumatera. 458(6), 298-306. https://doi.org/10.2991/assehr.k.200803. 037 
Malau, H. (2018). Nilai-nilai Masyarakat Adat Nagari Kapau Kabpaten Agam dalam Perspektif Self-Governing Community. Jurnal Teori dan Praktek Administrasi Publik, II(2)

Prahara, S. (2013). Kewenangan Badan Musyawarah (Bamus) Nagari Dalam Penyelenggaraan Pemerintahan Nagari Di Kabupaten Agam. Jurnal Pelangi, 6(1).

https://doi.org/10.22202/jp.v6i1.284

Pramukti, A. S., \& Cahyaningsih, M. (2016). Pengawasan Hukum Terhadap Aparatur Negara. Jakarta: Pustaka Yustisia.

Purwadi. (2017). Pengaruh Pengawasan Langsung dan Tidak Langsung terhadap Efektivitas Kerja Pegawai pada Dinas Pekerjaan Umum dan Pemukiman Prasarana Wilayah Kota Samarinda The Effect of Direct and Indirect Monitoring on Employee Effectiveness in Public Works Department a. Akuntabel, 14(2), 187-194.

https://doi.org/http://dx.doi.org/10.2926 4/jakt.v14i2.1911

Rahmanurrasjid, A. (2008). Akuntabilitas dan Transparansi dalam Pertanggungjawaban Pemerintah Daerah untuk Mewujudkan Pemerintah yang Baik Di Daerah (Studi Di Kabupaten Kebumen). Universitas Diponegoro Semarang.

Zenwen Pador, dkk. (2002). Kembali ke Nagari: Batuka Baruak jo Cigak. Padang: Lembaga Bantuan Hukum Padang.

Peraturan Bupati Pesisir Selatan Nomor 26 Tahun 2017 tentang Badan Permusyawaratan Nagari

Peraturan Daerah Kabupaten Pesisir Selatan Nomor 8 Tahun 2007 tentang Pemerintahan Nagari

Peraturan Daerah Provinsi Sumatera Barat Nomor 7 Tahun 2018 Tentang Nagari 